\title{
Assessing Quality of City Development by the Acquired Criteria of Landscape Urbanism
}

\author{
Gintaras Stauskis, Vaiva Deveikienè, Vilnius Gediminas Technical University
}

\begin{abstract}
We may see modern urbanism as a collection of many successful developments as well as a series of endless mistakes and repeated failures. The paper focuses on the analysis of existing and former urban planning and design patterns in aspect of efficiency of applied methods to achieve higher quality referring to the philosophy and practice of Landscape Urbanism. The Missionaries Block in Vilnius City serves as a case study for assessing its development in three distinguishable periods by the set of quality criteria derived from Landscape Urbanism theories and practices. The assessment results disclose an evident drop in the overall quality of the selected site's development in the recent period. The paper discusses if and how one may use the method employed hereby for programming and shaping the future regeneration and redevelopment of existing urban setting.
\end{abstract}

Keywords - Landscape, Missionaries Park, quality of development, quality indicator, trend, urbanism.

\section{INTRODUCTION}

In search of the advanced ways of thinking and best methods of planning and design, the natural, the legacy and the social layers of urban development are analysed as they emerge from the overall picture of a city. Traditional city attracts people to live, work and communicate, therefore this information could divert the recent trend in urbanisation from spontaneous sprawling mega-structure with low-identity massively replicated blocks to better solutions. The goal of the analysis is to discover the grounding principles for creating high quality urban spaces and districts from the analysis of the existing multi-layered development that has several time, style and society patterns. By analysing the quality features of the existing city, especial focus is on the natural layer of the place that serves as a ground for designing and constructing all urban structures. Uniformity of new urban structures has become a standard in our cities as the resulting impact of industrial construction methods and standardised technologies that indirectly and sometimes even directly rule the designing ways and methods used by urban planners and architects. This aspect comprises technology, machinery, infrastructure and building materials as well as equipment and even software used to design, erect and run the buildings. The question arises, how much standard technology should dominate over the design, especially when looking at the natural layer of the site. Currently, many cities entitled as modern have just poor remains of natural relief, water and vegetation systems that prevailed before their intense urbanisation happened and were lost in the process of rapid growth and industrial construction in the $19^{\text {th }}-20^{\text {th }}$ centuries. The dominating construction technology and growing need for infrastructure made these processes more severe and with no turning back. The question arises, could we measure the level of "modernity" by the level of extinction of the abovementioned natural features of a city as a whole and a taken site in particular. By analysing several recent urban projects that are located in urban areas with several legacy periods, the paper identifies the basic quality criteria of urbanism as regards landscape and gives the outlook of a common trend in time perspective.

The question of the role and the mission of landscape architecture has recently come back on the arena of urbanism, mainly because of numerous failings of modern urbanism based on conventional ideology of building the city by sophisticated composition of urban blocks. For many decades, activities of professionals that shape landscape architecture in the minds of many professionals who design the city is firstly associated with greening the developed land plots, gardening green areas and beautifying the remaining plot space of designed buildings. By identifying the quality criteria of landscape urbanism and employing them to assess modern urban design projects, the paper demonstrates the big scale of impact that landscape architecture can make in planning and designing the development of a modern city.

\section{Methodology and Research}

In order to assess the development of the selected urban site we need a set of qualitative criteria. For this reason, methodology of this paper starts with the analysis of values of Landscape Urbanism, its basic theories and the most advanced implemented projects. The comparison of these conclusions with the conventional practices show major differences from how the same or principally similar issues in urban development are solved using the advanced Landscape Urbanism methods and practices. Based on this comparison, we extract several distinguished features of urban design practices to represent the quality criteria for assessing the selected case in Vilnius City. In the next step, we assess the preselected urban site against these criteria while turning the qualitative criteria into quantitative grading. Finally, we obtain and discuss the summarised assessment results and drawn the conclusions. The authors of this paper performed the assessment by their personal perception of the site's recent and past development features using all available information, such as the site visits, photos, plans, drawings and written matter.

\section{A. Why Landscape Urbanism?}

Growing technical, environmental and social expectations of the developers and citizens have inspired the confluence of many disciplines in the field of modern architecture and engineering, and this practice has rendered better quality of created spaces and buildings by blending compositional, economic, environmental and social qualities of the project than isolated and fragmented 

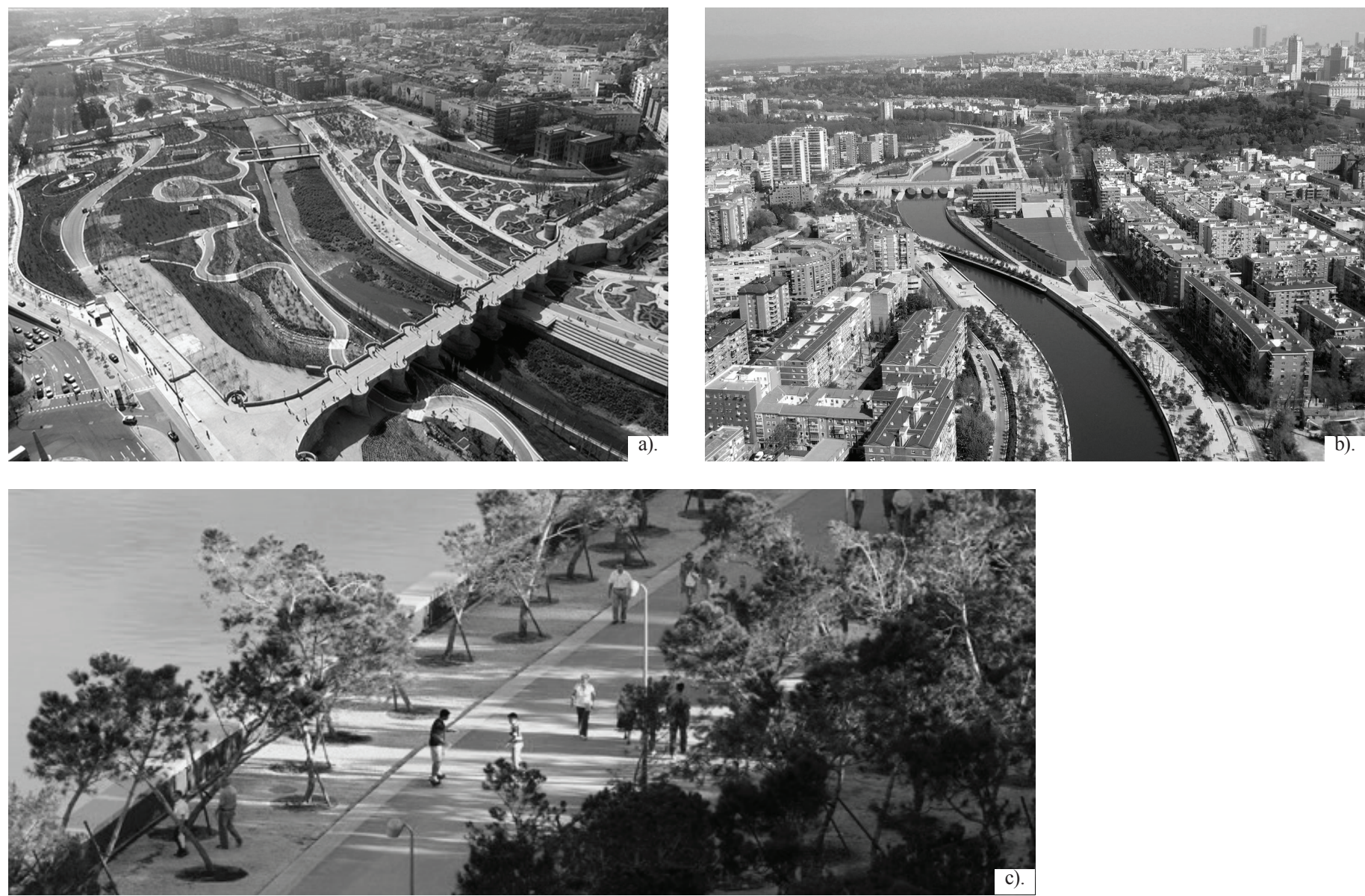

Fig. 1. Madrid Rio project. 2006-2011. a, b-aerial view; c-avenue view [12].

work of many specialists. In this context, interrelation of environmental and earth science has become a daily requirement in many leading projects, while in many others environmental issues are often treated as an obstructive barrier and process-delaying limitation. Some developers and architects treat urban legacy or public involvement requirements as inspiration, while the others - as obstruction. This regretful situations leads to the negligence of opportunities that nature, legacy and public involvement can give to create better projects and better places.

An assumption, that natural layer of urban area is the most important one and is prior to the layer of urban blocks and buildings, leads to the hypothesis that landscape may be more efficient organising element for a modern city than pure urban structure elements. Verification of this idea is the key goal of the paper.

The idea is less contradictive as it may initially look. We certainly perceive the city superficially through the spaces between the built structures of blocks and buildings. However, the conventional urban design methodology fails to provide clear answers to the question where and how these structures should appear, and where they should not. The methodology of landscape urbanism therefore paves the road to finding answers to more important questions, such as where the real values of the city lay and how they could and should be used.
In 1996, Tom Turner, one of the modern ideologists of Landscape Urbanism underlined: "The city of the future will be an infinite series of landscapes: psychological and physical, urban and rural, flowing apart and together" [1]. Christopher Alexander, one of the predecessors of Landscape Urbanism exclaimed: "A city is not a tree - it is a landscape" [2].

Landscape Urbanism ideas have attracted reaction from the competing urban paradigms, such as the New Urbanism, explicitly revealed in the critical book "Landscape Urbanism and its Discontents: Dissimulating the Sustainable City" (2013) where the authors acknowledged that "the New Urbanists were accustomed to critique, but the Landscape Urbanists' opposition involved something more fundamental. Their counter-proposal rested on an alternate model to claim the same territory utilizing different power bases, different methods of implementation, and different incompatible techniques" [3].

In Europe, the thinking as well as the turmoil around Landscape Urbanism has been less dynamic than in the USA where landscape architects in spite of more liberal economic policies have always been deeply involved in urban planning. For quite some time, there was a clear tendency of many European landscape architects to engage into understanding of context, issues of planning, urban politics and strategies instead of just single 

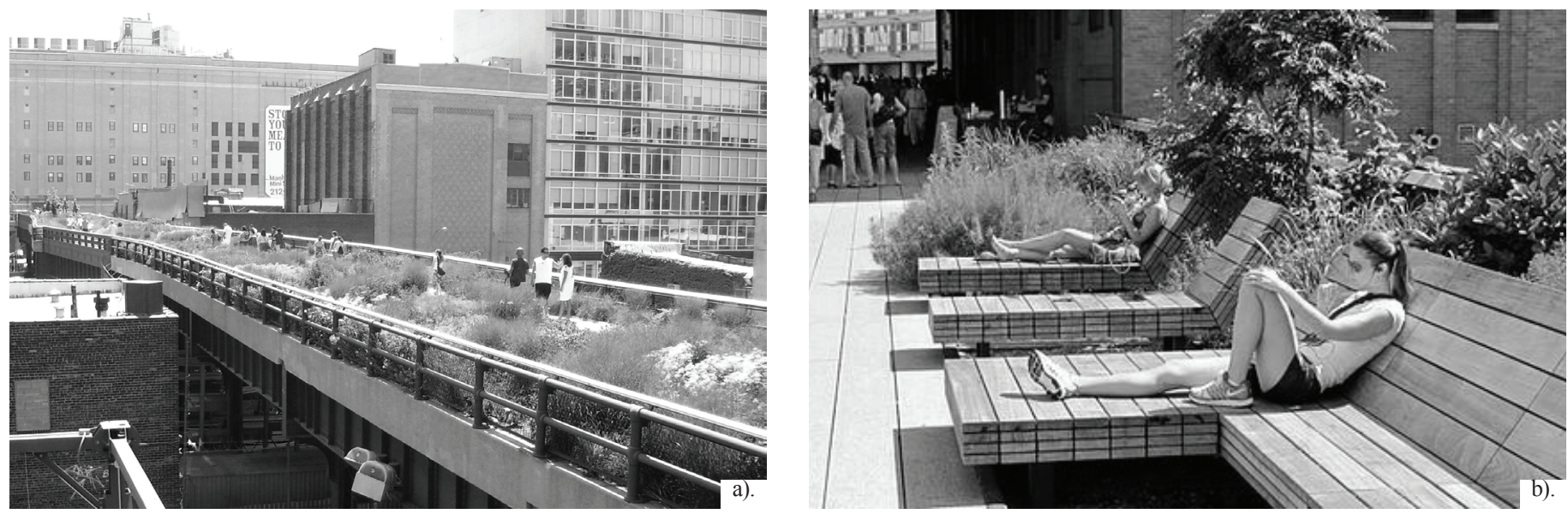

Fig. 2. a, b-Former tramline converted into a public space "High Line chill" across the $20^{\text {th }}$ street in New York [13].

site design [4]. In 1960, the German landscape architect Walter Rossow declared that landscape should be the foundation for a new city as well as any plan or layout of industrial cities, traffic routes or housing developments [5].

Landscape Urbanism has numerous roots, two of them being most evident: the heritage of many ancient civilizations in creating urban settlements and the history of both landscape architecture and urbanism. Landscape Urbanism strategy could become a powerful tool for negotiations between different actors within the 21st-century cities [6].

There are several distinctive trends for Landscape Urbanism thinking starting with Chinese Feng Shui, Indian Vastu and geomancy (geopathology) that represent the most ephemeric spheres of environment planning and space design known by some practicing planners and architects. Greenways, greenbelts and ecological networks are the practical tools how this philosophy implements and manifests itself. These traditions and ideas about landscape as infrastructure and landscape urbanism unite in the basic understanding of natural capital and ecosystem services merged with the concept of ecological infrastructure (Fig. 1). Ecological infrastructure builds the bridge between Landscape Urbanism and landscape ecology [7].

Considering the major themes that arise in this discourse, four main vectors arise: processes over time, horizontality, working techniques and methods, and the imaginary. Processes over time represent understanding and respect for fluid character of nature where all changes happen over time and therefore the planning should be open-ended, against finally completed solutions. Horizontality expresses itself by naturally horizontal development rather than vertically dominant proposals. Adaptation to the particular features of environment means possessing appropriate working techniques and planning methods. The loss of imagination to create new quality relation between the nature and urban setting marks the failure of the $20^{\text {th }}$ century planning and design.

All the above presented themes are from the pool of so-called "public goods" that we all strive to benefit from but the obtaining of them depends on how efficiently we organise the common processes of public management and employ good landscape planning and urban design to respond to the present issues [8]. The need for complex assessment of landscape in urban setting becomes more important while evaluating the future-looking urban redevelopment and landscape shaping proposals [9] where modern techniques and social media is used to obtain real, upto-date and rich information from the users [10].

\section{B. Empiric and Research Framework of Landscape Urbanism Quality Indicators}

The case study allows tracking the development of its features from the past periods until the present days in order to identify the quality features of Landscape Urbanism encrypted in the planning, design and management layers of the site. The Missionaries Convent and the church dominates the Missionaries urban block with the park located at the edge of Vilnius Old Town on an impressive slope that steps down through the garden and the park towards the Vilnia River. The first development on this site traces back as far as the $16^{\text {th }}$ century when Missionaries built the convent complex on the outskirts of Vilnius City. The block features the blend of urban structure developed on the impressive naturally sloping terrain, Vilnia riverbed and impressive vegetation volumes.

As the site given to the Convent features expressive topography, water and vegetation, the development masterly integrates into the existing landscape using flat platforms for buildings, gardening the slopes and installing ponds for managing storm water on the low areas. This approach safeguarded slopes and lowlands from being built-up that was complicated and costly taken the construction technology of the time. Different styles of development for upper and lower terraces were applied which once again emphasised the character of the sloped site.

The block has gone through numerous development phases with additions, demolitions and renewal. In mid and late $19^{\text {th }}$ century, the area attracted numerous industries that settled there because of comfortable access roads from the city to the country and available water from the artery of the Vilnia River that served 


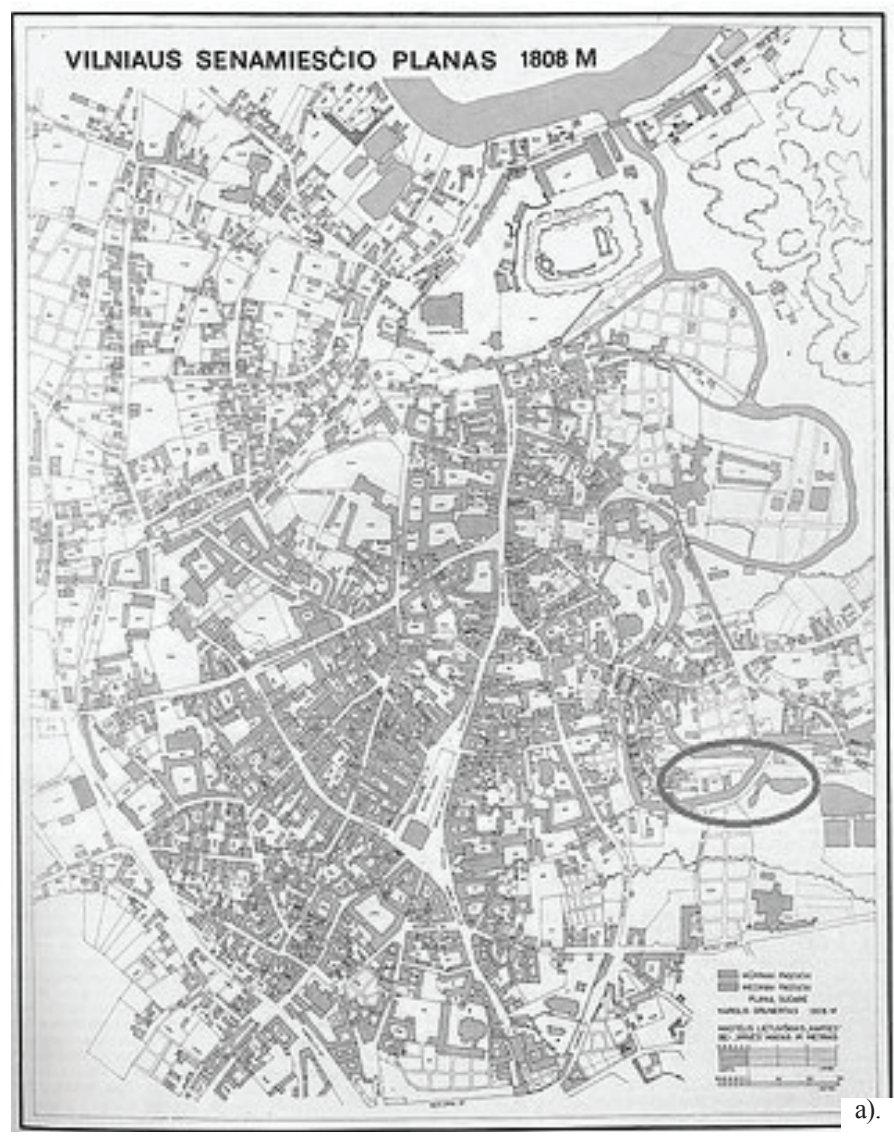

Fig. 3. a - Extract from Vilnius City plan in 1808; b - Photography of the development in 1861-1866 by Albertas Šveikauskas.

as energy and technology source for developing the production of timber, leather and textiles.

New housing blocks and the hospital altered the block in the 60 s of the $20^{\text {th }}$ century. The abandoned and underused post-industrial buildings in the block are attracting developers who recently came up with proposals for the new urban inclusions into this important piece of urban legacy in Vilnius City. In the light of recent sustainability strategy, numerous remains of buildings on previously developed land plots in local landscape raise a question of either the secondary use or demolition of these structures along with the recent need for comfortable and attractive public spaces.

Based on the analysed theories [11, 14-21], [11, 35-54] and advanced projects following the Landscape Urbanism mainstream principles (Fig. 1), (Fig. 2), the paper outlines the set of quality criteria that allow to measure and evaluate urban structure and the trend of its development in the recent period. Fourteen most influential indicators (Table I) focus on identifying, safeguarding and emphasising environmental, technical, social and compositional features of the site. The assessment of the Missionaries block against these indicators is performed for three pre-selected periods of its development that are clearly identifiable in the overall urban structure of this block by analysing photography and planning materials, design proposals, as well as by physical
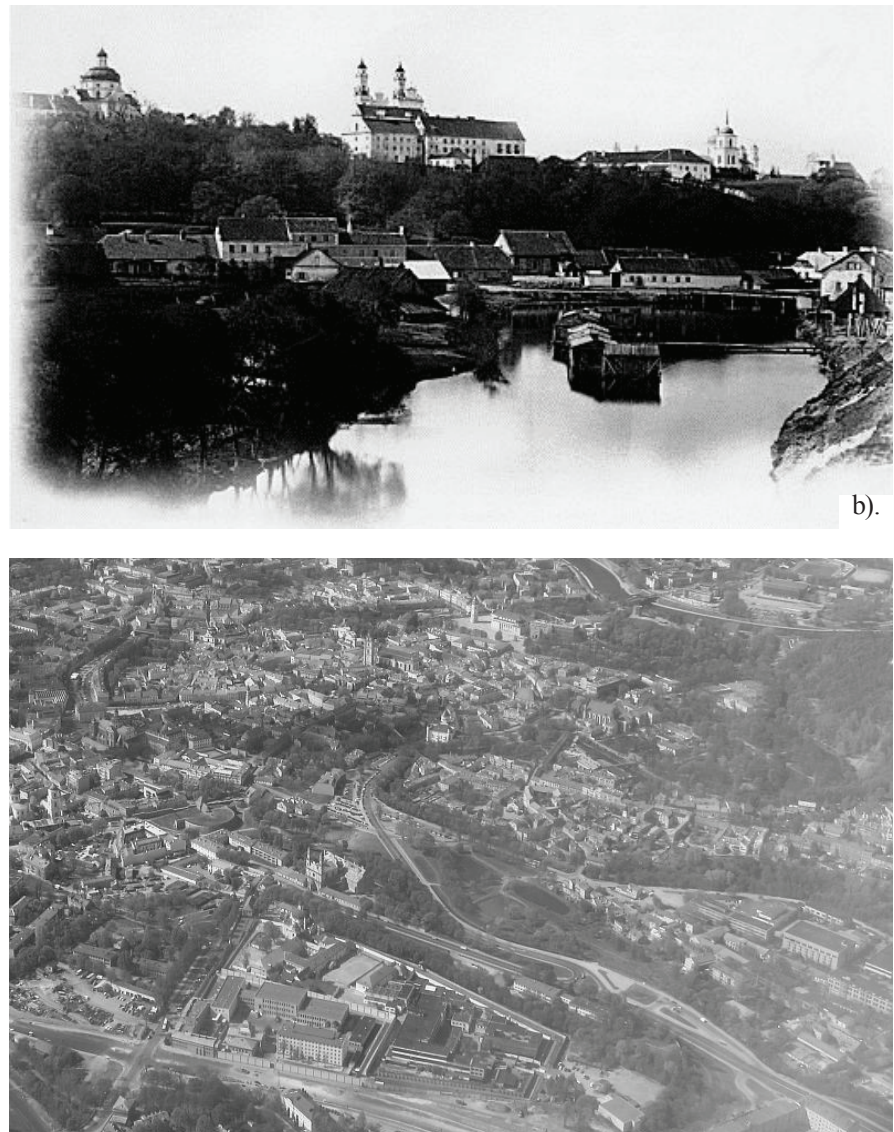

Fig. 4. Aerial picture of the site around 1980. Author unknown. [16]

observation and sensing the place. The formation of the block takes place from the oldest planning and development times $\left(16^{\text {th }}-17^{\text {th }}\right.$ centuries) until 1940, when it is finalised (Fig. 3). The period of 1945-1990 outlines the development during the period of the Soviet rule with specific political and socio-economic trends in urbanism, landscape and building architecture (Fig. 4). The recent period from 1990 until now, demonstrates the challenges of the $21^{\text {st }}$ century as they have manifested themselves in a clearly different context with current revitalisation and redevelopment proposals (Fig. 5, Fig. 6).

The assessment indicates the power by which the assessed urban site reflects in each of the 14 indicators and is recorded as + , ,+++++ , or,,------ , comparing it to the earliest outlined period $\left(16^{\text {th }}-17^{\text {th }}\right.$ century) that is taken as a status quo level. Plans, aerial and 3D views and skyline pictures are used for obtaining the assessment scores. The trend of development for the third most recent period comes as the comparison of its assessment indicators to the first and the second periods. As a result, the summary scores (number of positive $(+)$ or negative $(-)$ grades) appear in further comparison and discussion. 


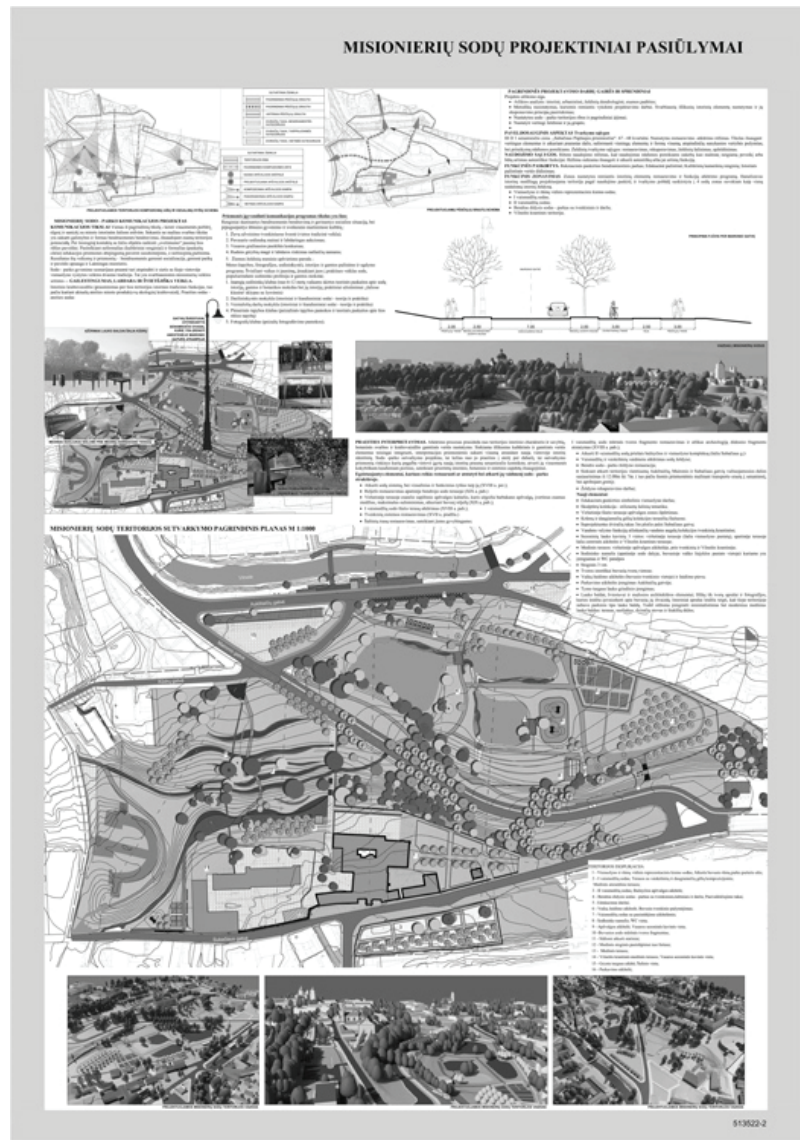

Fig. 5. The winning entry of the competition to plan the Missionaries Park area in Vilnius (2011) [14].
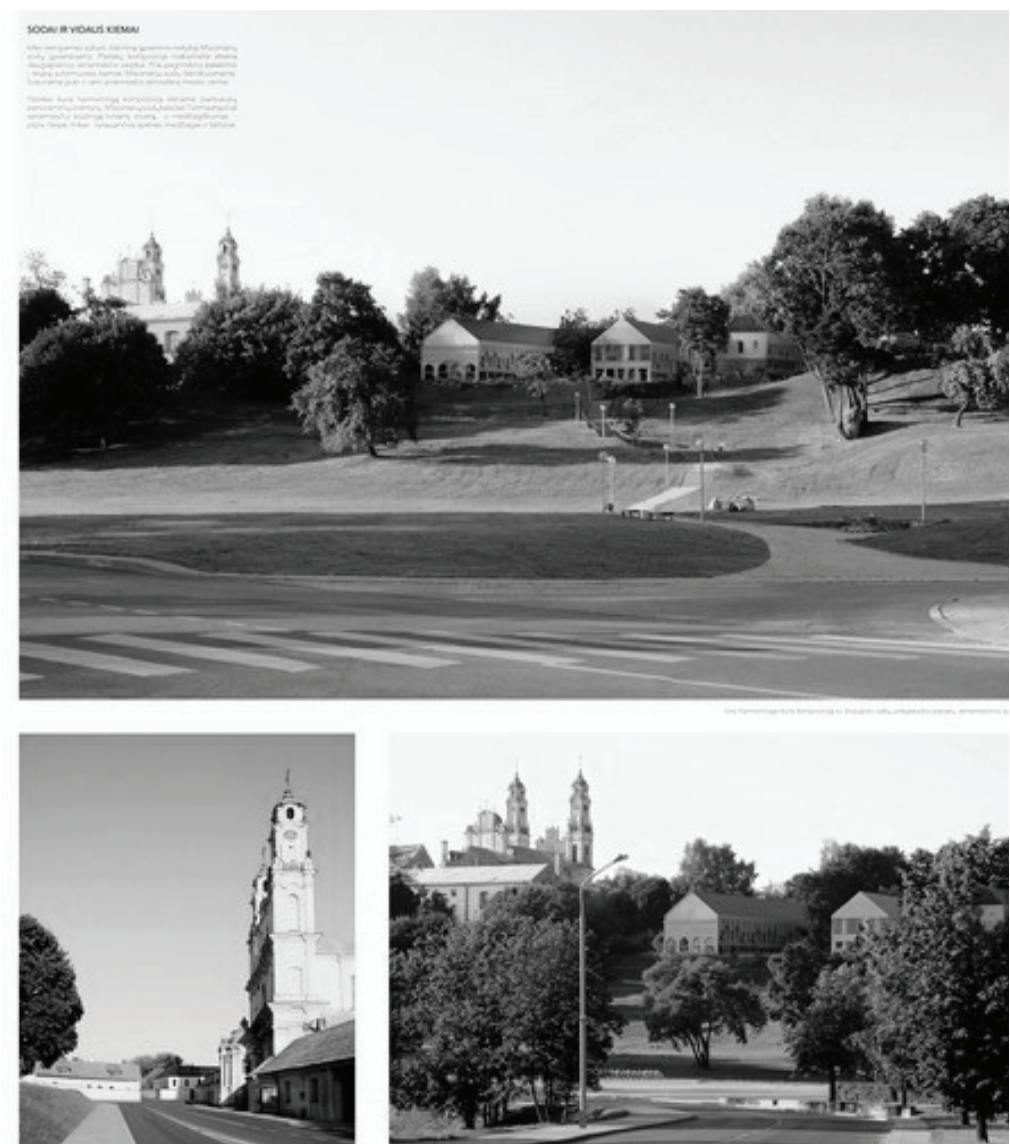

Fig. 6. The winning entry of the competition for residential complex beside the Missionaries Park (2014) [15].

\section{RESULTS}

The extent to which the development of the analysed Missionaries block complies with the preselected quality indicators is evaluated for the comparison of the initial historical development from the $16^{\text {th }}$ century through to the $20^{\text {th }}$ century and to present days. The results of the comparison show definite decrease in the quality of development in all 14 indicators (100\%) and, as a result, in 28 points of total 42 points $(67 \%)$. The next identified tendency is that the decline in the quality of development was varying in different indicators but essentially did not improve during the last 70 years (1945-2016). In addition, there is no overall improvement for the latest period of 1990-2016 as compared to the period from 1945-1990, featuring 28 and 27 negative points compared to the status quo level. As a trend, quality evaluation in 5 indicators has increased, in 5 indicators decreased and in 4 remained unchanged from the $2^{\text {nd }}$ to the $3^{\text {rd }}$ period. No sphere has clearly increased or decreased in quality, both trends are present.

\section{Discussion}

The assessment of development trends in the legacy areas is always a complicated multi-task operation that requires a clear method and comprehensive indicators based on a commonly acceptable value system. The results of assessing the development of Missionaries block through the three periods show that it is possible to identify the set of quality indicators for site evolution starting from a taken development period through and until the present days. In this particular way, the general quality criteria of Landscape Urbanism were adjusted to the place and space of the selected case study. These criteria should be both universal and individual, reflecting the whole timeline of the development of the taken place and not just one period, including also their social, economic and environmental sensibility. Application of these quality indicators for assessing the following development periods may give us timely and transparent notice of whether the coming additions and changes increase or diminish the overall quality of the taken urban area.

The authors admit that the set of 14 quality indicators may not be complete to describe all features of the place relating to generic and specific features for Landscape Urbanism; on the other hand, the assessment indicates the presence mainly of those qualities that the authors have identified in the current case of the Missionaries block in Vilnius City. This list is flexible and could extend further, given different specific features of selected cases are identified. 
TABLE I

Results of Quality Assessment in Three Time Periods (Authors of the Article)

\begin{tabular}{|c|c|c|c|c|}
\hline \multirow[t]{2}{*}{ Theme } & \multirow[t]{2}{*}{ Indicator } & \multicolumn{3}{|c|}{ Assessment index, trend } \\
\hline & & $16^{\text {th }}$ c. -1940 & 1945-1990 & $1990-2016$ \\
\hline \multirow[t]{3}{*}{ Eco-environmental } & $\begin{array}{l}\text { 1. Safeguarding valuable } \\
\text { ecological features of the site }\end{array}$ & +++ & ++- & $+--\downarrow$ \\
\hline & $\begin{array}{l}\text { 2. Preserving valuable land } \\
\text { segments from development }\end{array}$ & +++ & --- & --- \\
\hline & $\begin{array}{l}\text { 3. Sensing individual } \\
\text { development patterns for } \\
\text { different terrain }\end{array}$ & +++ & --- & $+--\uparrow$ \\
\hline \multirow[t]{4}{*}{ Infrastructural - technical } & $\begin{array}{l}\text { 4. Secondary use of built } \\
\text { areas and land plots }\end{array}$ & +++ & --- & $+--\uparrow$ \\
\hline & $\begin{array}{l}\text { 5. Secondary use of buildings } \\
\text { and facilities }\end{array}$ & +++ & --- & $++-\uparrow$ \\
\hline & $\begin{array}{l}6 . \text { Using local natural } \\
\text { building and planting } \\
\text { materials }\end{array}$ & +++ & ++- & $+--\downarrow$ \\
\hline & $\begin{array}{l}\text { 7. Inclusive design of } \\
\text { integrated urban mobility } \\
\text { solutions }\end{array}$ & +++ & ++- & $+--\downarrow$ \\
\hline \multirow[t]{3}{*}{ Socio-functional } & $\begin{array}{l}\text { 8. Generating solutions for } \\
\text { resident's recreation }\end{array}$ & +++ & ++- & $+--\downarrow$ \\
\hline & $\begin{array}{l}\text { 9. Opening the site for } \\
\text { comfortable user access }\end{array}$ & +++ & ++- & ++- \\
\hline & $\begin{array}{l}\text { 10. Protecting and creating } \\
\text { attractive public places and } \\
\text { spaces }\end{array}$ & +++ & +-- & $++-\uparrow$ \\
\hline \multirow[t]{6}{*}{ Aesthetical creative } & $\begin{array}{l}\text { 11. Applying natural spaces } \\
\text { and forms in urban design } \\
\text { solutions }\end{array}$ & +++ & +-- & $---\downarrow$ \\
\hline & $\begin{array}{l}\text { 12. Integrating architectural } \\
\text { design in natural skyline }\end{array}$ & +++ & +-- & +-- \\
\hline & $\begin{array}{l}\text { 13. Applying architectural } \\
\text { dominants of development on } \\
\text { naturally staged terrain }\end{array}$ & +++ & --- & --- \\
\hline & $\begin{array}{l}\text { 14. Integrating natural } \\
\text { elements in architectural } \\
\text { design of buildings }\end{array}$ & +++ & +-- & $++-\uparrow$ \\
\hline & Total: & 42 & 14 & 15 \\
\hline & Trend: & & -28 & -27 \\
\hline
\end{tabular}

The trends in quality of the two last periods of analysis as compared to the initial historical period are shockingly similar and strongly negative, which is the main disappointment. This may mean that something essential may have been lost during time, especially comparing 1950 s during the Soviet rule with modern period from 1990-2016. Having in mind the limited design and construction techniques of the 50s and practically unlimited technological and design possibilities of today the tendency is even more shocking. In spite of evident technical advancement, the overall quality of urban development is not increasing, as one would expect. To some extent, regeneration of post-industrial buildings is vague because of legal and environmental regulations and many other related obstacles such as contaminated soils and others. Therefore, developers and authorities should look for and find positive pathways in designing modern development by searching for the essential features of traditional city in relation to landscape. These features and methods may have altered or lost in the recent urban and architectural design period. The basic features of a traditional city are essentially the ones that were used in the survey (Table I) and which distinguish Landscape Urbanism from the prevailing mainstream urbanism that brings urban sprawl, abandonment and uniformity. The question remains, is it possible to project the outlined quality indicators on the evaluation of future design proposals? The future of urban areas should be analysed in a much wider context, as they may rely on different urban concepts and consecutively may require a different value assessment system. 


\section{CONCLUSION}

The analysis of the basic principles of Landscape Urbanism theories and practices may deliver objective and comprehensive quality indicators that reflect on the way that the taken urban development has changed from its past state to the current one. Applying of these indicators to assess the selected periods of development may indicate the trend of quality change for a taken area. The Missionaries urban block in Vilnius City that is the case for testing this method has rendered the set of quality indicators. The assessment results clearly reveal the negative trend in the overall quality change as compared to the early periods of development on this site.

The method presented hereby may also serve as a tool for drafting the strategy for further regeneration of urban areas that had multiple periods of development. In addition, it may set the ground for creating the concepts of improving spatial arrangement quality of the existing urban blocks.

\section{REFERENCES}

1. Turner, T. City as landscape : A Post Post-Modern View of Design and Planning, London: E\&FN Spon, 1996. 248 p.

2. Alexander, C. A Pattern Language. Oxford: Oxford University Press, 1978. $1216 \mathrm{p}$.

3. Duany, A., Talen, E. Landscape Urbanism and its Discontents : Dissimulating the Sustainable City. Gabriola Island, Canada: New Society Publishers, 2013. $328 \mathrm{p}$.

4. Andersson, T. Landscape urbanism versus landscape design. Topos 71 : Landscape Urbanism, 2010. p. 80-83.

5. Bunge, J., Feldschmid, P. Back to GO. Clear and obstructed paths in the planning disciplines. Topos 71 : Landscape Urbanism, 2010. p. 84-88

6. De Meulder, B., Shannon, K. Traditions of landscape urbanism. Topos 71 Landscape Urbanism, 2010. p. 69-73.

7. Yu, K. Five Traditions for Landscape Urbanism Thinking. Topos 71 Landscape Urbanism, 2010. p. 58-63.

8. Turner, T. Landscape Planning and Environmental Impact Design. London: UCL Press, 1998. 438 p. https://doi.org/10.4324/9780203214534

9. Giovanni, D. Towards Interaction-based urban design [online]. Youtube [cited 15.06.2016]. http://t.co/6LmWJ3AUN9

10. A Sense of Place : Exploring the potentials and possible uses of Location Based Social Network Data for urban and transportation planning in Turku City Centre [online]. Spin Unit [cited 15.06.2016]. http://www.spinunit.eu/ portfolio/a-sense-of-place

11. Waldheim, C. The Landscape Urbanism Reader. New York: Princeton Architectural Press, 2006. 288 p.

12. Madrid Rio 2006-2011 [online]. West 8 [cited 02.01.2016]. http://www. west8.nl/projects/madrid rio/

13. Berkowitz, D. High Line Park NYC - Manhattan - New York City [online]. Flickr [cited 02.01.2016]. http://www.flickr.com/photos/davidberkowitz/5923557984/ Licenced under CC BY $2.0 \mathrm{https} / / /$ commons.wikimedia org/wiki/File:High Line chill.jpg\#/media/File:High Line chill.jpg

14. Misionierių sodų Vilniuje konkurso rezultatai [online]. Lietuvos Architektu sajunga [cited 02.01.2016]. http://www.architektusajunga.lt/naujienos/ misionieriu-sodu-konkursas

15. Gyvenamojo komplekso „Misionieriu sodai“ Subačiaus g. Vilniuje konkursas [online]. Lietuvos Architektu sajunga [cited 02.01.2016]. http://www. architektusajunga.1t/las-konkursai/pasibaige-konkursai-2014-m/gyvenamojo-komplekso-misionieriu-sodai-subaciaus-g-vilniuje-konkursas-1

16. Misionieriu sodo nuotraukos iš oro [online, cited 02.01.2016]. http://foto. terpe.lt/inkelti/20110413/i75 6 5\%20priedas\%20(foto).jpg

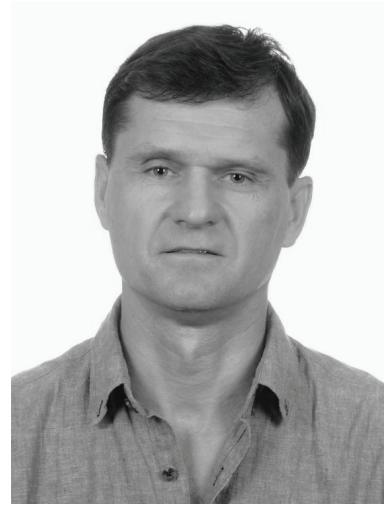

Gintaras Stauskis, Doctor of the Humanities, is a Professor with Vilnius Gediminas Technical University conducting academic research at the Department of Urban Design. He is involved in European Union collaborative research programmes. His current research fields are green architecture, sustainable urbanism, accessibility of environment, health care networks, urban recreation. Research results are presented in a number of national and international publications and conferences.

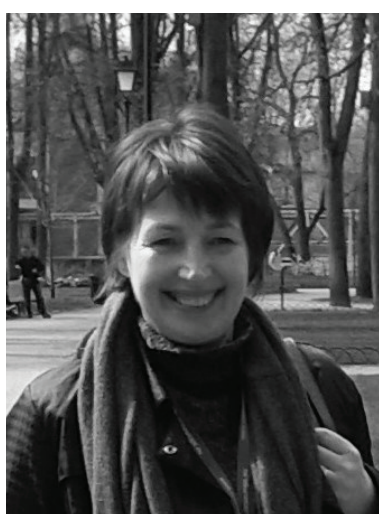

Vaiva Deveikienè is a Landscape Architect with long and successful career and practical experience. She is currently working on landscape issues at Vilnius City Municipality. She is also carrying out a $\mathrm{PhD}$ research on the topic of interaction between the landscape architecture objects and urban context. She has publications on the topics of landscape legacy, urban landscapes, training and related themes.

\section{Contact Data}

\section{Gintaras Stauskis}

Vilnius Gediminas Technical University

Department of Urban Design

Address: 1 Trakų St., Vilnius, LT-01132, Lithuania

E-mail: gintaras.stauskis@vgtu.lt

\section{Vaiva Deveikienė}

Vilnius Gediminas Technical University

Department of Urban Design

Address: 1 Trakų St., Vilnius, LT-01132, Lithuania

E-mail: vaivadeveikiene@gmail.com 